\title{
The Relationship between Perceptual Learning Styles and Reading Comprehension Performance of Iranian EFL Learners
}

\author{
Milad Chavosh $^{1} \&$ Mohammad Davoudi ${ }^{1}$ \\ ${ }^{1}$ Department of English Language and Literature, Hakim Sabzevari University, Iran \\ Correspondence: Mohammad Davoudi, Department of English Language and Literature, Hakim Sabzevari \\ University, Iran. E-mail: davoudi2100@gmail.com
}

Received: March 23, 2016 Accepted: April 15, 2016 Online Published: May 25, 2016

doi:10.5539/ijel.v6n3p61 URL: http://dx.doi.org/10.5539/ijel.v6n3p61

\begin{abstract}
Reading comprehension is one of the most important aspects in the process of language learning. Individual differences in foreign language learning have also been a common theme among L2 researchers and various factors such as gender, aptitude, motivation, and learning styles have been the subject of numerous studies indicating their effect on language learning. Along the same lines, this study focused on the relationship between perceptual learning styles and L2 reading comprehension and how well each perceptual learning style contributes to L2 reading comprehension. The study was carried out on 60 Iranian foreign language learners. The results of statistical analyses indicated that only tactile and kinesthetic learning styles had a significant relationship with L2 reading comprehension performance. Moreover, the findings of the study revealed that the tactile learning style was the best predictor of L2 reading comprehension performance. Based on the findings of the study, it can be concluded that teachers should try to accommodate different learning styles in teaching reading comprehension. If the educational settings become compatible with the learners' personal orientations, learners may be able to engage in educational activities more and will thus gain an advantage in learning.
\end{abstract}

Keywords: reading comprehension, individualistic, group, tactile, visual, auditory, kinesthetic, learning styles

\section{Introduction}

Reading is one of the language skills people use for various purposes such as pleasure, education, art etc. Mikulecky $(2008$, p. 1) maintains that "Effective reading is essential for success in acquiring a second language. Reading is the basis of instruction in all aspects of language learning. Through reading, everyone can make meaningful inferences along with receiving writers' textual productions. In different cultures, reading is considered as a sign of mastery. Therefore, concerning reading as a critical skill in language learning, the majority of L2 learners relate their success in learning a language to their accomplishment in reading the texts in that language (Nunan, 1998). Thus, reading comprehension is a process which can lead to an improvement in the cognitive ability of the individuals (Mikulecky, 2008). In the context of education, how we perceive and process information is called learning style which is argued by Kinsella (1995) to be operating independently from instruction methods and from content.

\section{Literature Review}

\subsection{Reading Comprehension}

Over past years, various definitions for reading have been provided in L2 learning literature. Generally speaking, getting the exact and detailed message from a text is considered to be the main aim of reading (Nuttal, 1996). Recently, the conceptualization of reading has improved and has moved from a receptive process to an interactive one (Ellis, 2008). The reader goes through two major reading comprehension processes while reading a text: bottom-up processing and top-down processing. Through bottom-up processing, the readers can get the meaning from the scripts and words of a text and reconstruct the intended message in that way (Chastain, 1988; Ellis, 2008) while in top-down processing, the reader looks at a text as a whole and relates the concepts to his prior background knowledge base (Chastain, 1988; Ellis, 2008). It is worth mentioning that both processes are necessary in getting a message from a text.

Conventionally, many psychologists and language teachers are of the view that reading is nothing more than interpreting the written symbols to sounds, which means comprehending what the written text says. According to 
Nuttal (1996), in the past, the reader was considered as the "receiver" of information or as an "empty vessel" that brought nothing to the script. This movement of "text as object" is now frequently questioned in reading circles because readers are not completely passive. Recently, a large number of researchers consider reading process as an active process in which reading skills can be established (Chastain, 1988).

The perspective of teaching reading has changed from teaching the "text as object" to that of the "text as process" in which the communication between the reader and the text is encouraged. Along with model-making in L2 reading in the past decades, the consideration has been paid to knowing what proficient, skilled language learners usually do when reading, trying to identify the approaches they use and how and under what conditions they use such approaches. This type of research has been respected in teaching not only by non-proficient readers, but also by L2 readers in order to improve their awareness and apply reading strategies so as to improve comprehension (Garner \& Alexander, 1989). According to Durgunoglu \& Hancin-Bhatt (1992), reading is made up of an integration of multiple subcomponents. In its broadest sense, reading involves converting written symbols into a visual code leading to the activation of meaning of that visual code. This will yield a meaning-construction process. As with the other three language skills, reading theory has faced ups and downs both in the area of teaching and learning. As Darnton (1984) has pointed out, a century ago reading was viewed as loud recitation of prominent religious scripts including prayers and biblical excerpts.

During the1950s and the 1960s, top-down and bottom-up theories gained dominance. The former involves a focus on what the individual brings to the text. That is, the reader seeks the information in the text. Then, he/she contrasts it against his/her global knowledge of the world. Consequently, the reader derives the meaning from the text (Yang et al., 2006). As for bottom-up process, the reader begins with the text and the words, proceeding to paragraphs and world knowledge to construct the final meaning.

Current perspective on reading views comprehension as a multi-level cognitive process thereby a reader engages in constructive interactions with a text to derive meaning (Grabe, 1991; Pang et al., 2004). This approach draws on interaction and social constructivism. In the same vein, the recent research is focused on reading from social construction perspective. According to Yang et al. (2006), social constructivism accounts for the way in which learning, in general, and reading, in particular, can be strengthened through interactions. Based on this approach, "learning occurs in a socio-cultural context and learners are considered as the individuals actively constructing their own learning environment" (Mitchell et al., 1988, p. 162). That is, learning does not take place in an isolated fashion.

One of the main challenges facing readers is the extensive set of vocabulary used in reading. As Pang et al. (2004) have made it clear, lexical knowledge plays an essential role in reading comprehension in both first and second language. Similarly, a study conducted by Garcia (2000) concluded that the lack of lexical knowledge was one of the major linguistic factors influencing the reading performance of L2 learners negatively. Vocabulary can be reinforced through reading. A look at literature reveals that reading has been categorized into two main types, i.e. extensive reading and intensive reading. Intensive reading involves focused reading where the reader covers a large volume of text within a short time. However, the focus of many studies has been on extensive reading where the reader reads as many texts as he/she can read (Gorsuch, 2012). However, as Erfanpour (2013) has emphasized, these two approaches complement each other.

\subsection{Learning Styles}

According to Montgomery (1995), the observation that an individual can learn more effectively when he/she receives the information and processes it in a manner tailored to his/her preferred methods underlies the attempts made at investigating various learning styles. A learning style may appear as a dominant style out of many for an individual. Yet, it does not imply that the same individual cannot proceed with other styles; the learners will learn more effectively when the learning accords with their dominant learning style. As a result, educators and teachers should consider learning styles only as a guideline and not a rigid set of rules. Similarly, Dunn \& Dunn (1979) assert that learning style as a set of characteristics which are determined biologically render a teaching method enjoyable and useful for some and thorny for others. In other words, the learning may not be influenced by some styles while it may be influenced by some others. In the same vein, it is of great importance to identify students' learning styles so that they can be drawn on to improve learning outcomes.

When it comes to the correlates of learning style, the bulk of studies conducted in this respect reveal that different English Language Learners (ELLS) have different patterns of learning style (Butler, 1988; McCarthy, 1990; Sims \& Sims, 1995). The findings of these studies have indicated that language learning style is influenced by various factors including personality type, sex, and area of study, perception, and age (Aydogan \& Akbarov, 2014). Furthermore, the findings also show that learners vary on the use of the type and the frequency of learning 
styles, depending on their cultural experiences, nationality, and various learning settings.

Undoubtedly, different researchers proceed with classifying the language learning styles differently. Tuan (2011) states that due to the fact that learning styles have been defined differently with regards to both breadth and depth, it is difficult to deal with all of them simultaneously. However, a look at literature shows that some classifications given by scholars are used more frequently by other studies. For instance, James \& Gardner (1995) categorize various learning styles based on three main dimensions: (1) perceptual, (2) cognitive, and (3) affective. Alternatively, as Griggs (1991) and Swanson (1995) have argued, various learning style models can be classified through drawing on personality models, models of social interaction, modes of information processing and models of instructional preference. Yet, some scholars such as Gentry (1990) have classified learning style in terms of physical and sensory preferences (for example, visual, tactile, and auditory). Furthermore, psycholinguistics and education have been implicated in the classification of learning styles. In these two fields, learning styles are classified, using the component of brain hemisphericity. According to Asselin \& Mooney (1996), the right brain is linked with learners' global styles and the left brain is associated with learners' analytic styles. The classification proposed by Nunan in 1991 has been frequently adopted by many studies. The way in which individuals learn language input constitutes the basis of Nunan' classification of learning styles. According to this model, there are 4 types of learning styles as follows:

1) Concrete style: Individuals process information directly. These learners use their senses such smelling, touching, and vision to record the information they have taken in. Their perspective to things is tangible, fact-based and literal.

2) Analytical style: Individuals are led by their cognitive strengths to analyse accurately as well as by attaching enormous significance to demonstrating their independence by independently engaging in their tasks and activities. These learners tend to study individually, spotting their own errors and problems while doing tasks.

3) Authority-oriented style: These individuals are interested in their teacher's full explanation and they have the tendency to continuously take note in their notebook. These people are oriented toward studying grammar rules as well as learning by reading.

4) Communicative style: These learners are interested in using social learning approach. They prefer learning a language by engaging in social activities such as meeting native speaker and talking to them, watching the videos in L2, having chats with friends in English, using English out of the class, expanding their vocabulary by hearing and learning in the context of conversation.

Reid (1995) defines learning styles as characteristics that are internal and most often used unconsciously. He categorizes learning styles into three main groups: cognitive styles, sensory styles, and personality styles. Furthermore, cognitive learning styles could be categorized into the following pairs: learners who are field-dependent vs. those who are field-independent; learners who are analytic vs. those who are global; and learners who are reflective vs. those who are impulsive. Individuals who are field-independent learn best in step by step manner, starting with the analysis of facts and moving on to ideas. In contrast, field-dependent individuals tend to learn best holistically in context (Salmani-Nodoushan, 2007; Shi, 2011; Soozandehfar \& Soozandehfar, 2011; Swanson, 1995). Analytic persons can learn best individually by setting their learning objectives whereas global persons learn most fruitfully when they are engaged in concrete experience and through interactions with others (Scarcella, 1990). Reflective persons possibly learn best when they are provided with ample time to take into account all potential things before giving any response. In contrast, impulsive persons can respond instantly, preferring taking risks (Lee \& Kim, 2014).

At the same time, we can divide sensory learning styles into three main categories as follows: perceptual styles, environmental styles, and personality styles. These general learning styles, in turn, are sub-divided into learning style preferences depending on traits and individuals' learning. Learners having perceptual learning style tend to make more frequent use of their senses (i.e., hearing, sight, touching, tactile) in their group and individual interactions. These learners can learn a language best by appealing to hearing, looking, and tactile sense. Literature shows that scholars have divided environmental learning styles into two main categories, namely, physical and sociological. Physical styles belong to learners who can learn best when the following variables are taken into account: temperature, brightness, and time and space management. Learners of sociological style learn best when factors such as group, co-working, team work, and the extent of teacher authority are considered in learning (Kratzig \& Arbuthnott, 2006; Pourhossein Gilakjani, 2012, Tight, 2010).

Learners' personality can be used to classify personality learning styles in terms of various learning types. Extroverts are eager to experience concrete activities, interactions with outside people, establishing new relationship with others. In contrast, introverts are more eager to be in independent circumstances. Sensing 
persons can learn more effectively when they are given reports and briefings on observable facts and events. In fact, they rely on their five senses. Perception persons learn more effectively when they are embedded in meaningful experiences. Thinking person can have the highest level of learning from impersonal situations and logical outcomes. In contrast, feeling persons appeal to personalized situations and social values. Judging persons can learn in the best manner when they reflect, analyse, and process, while perceiving persons learn by engaging in processes such as negotiation and feeling which may postpone closure. Ambiguity-tolerant persons' desired learning materializes when they are provided with opportunities for experience and risk (Estadt, 1997; Le Sage, Venneman, Patton, \& Hallock, 2008; Larrabee, 2005; Tuan, 2011).

\subsection{Objectives of the Study}

Learning styles have been shown in several studies to have influenced the way in which a person learns, comprehends, and produces language. Identifying students' learning styles has been found to be a significant factor in effective instruction and learning quality. The aim of this paper was to address some of the fundamental questions about learning styles. The existing literature on learning styles and the interrelationship between learning styles and reading comprehension has illustrated that a variety of factors, such as learners' previous reading experiences, educational background, gender, age, reading preference or text-specific factors influence reading comprehension. In this way, learning styles and reading strategies are crucial factors that are in need for an investigation in the EFL setting. Since EFL learners may have different learning styles and employ a broad spectrum of reading strategies, including oral reading and silent reading, which may reflect on their reading comprehension, there is a dire need for examining the relationship between learners' reading strategies and their learning styles in EFL settings. The purpose of this study was to examine if perceptual learning styles could predict the reading comprehension of Iranian EFL learners.

\section{Research Questions:}

To explore perceptual learning styles of Iranian EFL learners, the present study strives to find answers to the following research questions:

Q1: Is there any significant relationship between perceptual learning styles and reading comprehension performance of Iranian EFL intermediate learners?

Q2: Which one of the learning styles best predicts the reading comprehension performance of Iranian EFL intermediate learners?

\section{Method}

\subsection{Participants}

Initially, 90 intermediate language learners took the PET (preliminary English Test) based on which the most homogenized language learners in terms of overall language proficiency were selected. The selection process of the participants of the study was based on closeness of students' scores to mean score on PET. To this end, students whose scores fell between +1 and -1 standard deviation were included in the study. Finally, 60 foreign language learners were selected as the participants of the study.

\subsection{Research Instruments}

\subsubsection{Preliminary English Test (PET)}

Preliminary English Test (PET), the Cambridge Preliminary English Test, or PET for short, is a qualification in English as a Foreign Language awarded by Cambridge ESOL. This test was used to measure the overall language proficiency and reading competence of the participants of the study. The test has these sections: A-Reading Writing taken together - 90 minutes; B-Listening - 30 minutes; C-Speaking - an interview, 10 minutes.

\subsubsection{Perceptual Learning Styles Preference (PLSP)}

In addition to the PET which was a language proficiency test, a Perceptual Learning Styles Preference (PLSP) survey was also used. This instrument which was developed by Joy Reid in 1984 is the first learning style questionnaire widely known in the ESL/EFL field. It is a self-reporting scale developed using available learning style instruments with the modifications inspired by opinions by non-native speaker scholars and US linguists. It contains 30 items and participants are required to respond by choosing one of the options "Strongly agree" (1 point), "Agree" ( 2 points), "Undecided" ( 3 points), "Disagree" (4 points) to "Strongly disagree" (5 points). The survey measures 6 perceptual learning styles as visual (questions: 6,10,12,24,29); auditory (questions: $1,7,9,17,20)$; kinesthetic (questions: 2,8,15,19,26); tactile (questions: 11,14,16,22,25); group learning (questions: $3,4,5,21,23$ ); and individual learning (questions: 13, 18, 27, 28, 30). Respondents should complete the 
questionnaire in 20 minutes and each preference category has the score range of 5 to 25 . In order to avoid any misunderstanding due to language difficulties, the Persian version of PLSP survey by Riazi and Mansoorian (2008) was used in the resent study. The reliability of Perceptual Learning Style Preferences Survey was found 0.78 using the Cronbach's alpha.

\subsection{Procedure}

Three foreign language institutes in Yazd, a city in the center of Iran, agreed to cooperate with the researchers in carrying out the project. Each institute provided the researchers with a list of intermediate language learners based on which 90 foreign language learners were selected as the candidates. They took the PET and according to their scores, 60 students whose scores fell between +1 and -1 standard deviation were chosen to participate in the study. In needs to be noted that the participants of the study took part in the study voluntarily. Following that, PLSP was introduced to the students and they were instructed on how to complete the questionnaire. Afterward, the questionnaires were collected and scored. Based on the scoring system explained above, each perceptual preference could range from 5 to 25 . The scores obtained from learning style survey and reading section of PET were analyzed using SPSS through statistical technique of multiple regression and Spearman correlation coefficient for estimating prediction power of perceptual learning styles on L2 reading comprehension and finding the correlation of each perceptual learning styles with L2 reading comprehension respectively.

\section{Results}

Results of Pearson correlation coefficient showed that only kinesthetic learning style and tactile learning style had significant correlation with L2 reading comprehension. Table 1 shows the correlation coefficient of each perceptual preference with 12 reading comprehension.

Table 1. Results of spearman correlation coefficient between perceptual learning styles and L2 reading comprehension

\begin{tabular}{lll}
\hline & & Reading Comprehension \\
\hline Visual Learning Style & Pearson Correlation & .079 \\
& Sig. (2-tailed) & .547 \\
Auditory Learning Style & Pearson Correlation & -.104 \\
& Sig. (2-tailed) & .428 \\
Kinesthetic Learning Style & Pearson Correlation & $.257^{*}$ \\
Tactile Learning Style & Sig. (2-tailed) & .047 \\
& Pearson Correlation & $.379^{* *}$ \\
Individualistic Learning Style & Sig. (2-tailed) & .003 \\
Group Learning Style & Pearson Correlation & .101 \\
& Sig. (2-tailed) & .444 \\
& Pearson Correlation & .146 \\
& Sig. (2-tailed) & .265 \\
\hline
\end{tabular}

Kinesthetic learning style had a correlation coefficient of 0.25 with significant value of 0.04 and tactile learning style had a correlation coefficient of 0.37 with significant value of 0.00 . Only these two perceptual learning styles had correlation coefficient with significant values less than 0.05 and the rest of perceptual learning styles had correlation coefficient with significant values greater than 0.05 .

Regarding the prediction power of perceptual learning styles on L2 reading comprehension, the obtained data were analyzed through standard multiple regression analysis and all predictors were entered using standard procedure. The analysis revealed $\mathrm{R}$ square as 0.213 which indicates that perceptual preferences account for $21 \%$ of the variance in reading comprehension scores. In other words, perceptual styles predict $21 \%$ of the reading comprehension scores. Table 2 shows the model summary of regression analysis. 
Table 2. Model summary of regression analysis

\begin{tabular}{lllll}
\hline Model & $\mathrm{R}$ & R Square & Adjusted R Square & Std. Error of the Estimate \\
\hline 1 & $.462^{\mathrm{a}}$ & .213 & .124 & 3.68943 \\
\hline
\end{tabular}

This amount of prediction was found significant as analysis of variance showed $\mathrm{F}$ value of 2.39 with significant level of 0.04 which is less than confidence interval of 0.05 . Table 3 shows the results of analysis of variance.

Table 3. Analysis variance indicating the significant of prediction power of perceptual preferences on reading comprehension scores

\begin{tabular}{lllllll}
\hline Model & & Sum of Squares & df & Mean Square & F & Sig. \\
\hline 1 & Regression & 195.555 & 6 & 32.592 & 2.394 & $.040 \mathrm{a}$ \\
& Residual & 721.429 & 53 & 13.612 & & \\
& Total & 916.983 & 59 & & & \\
\hline
\end{tabular}

The contribution of each perceptual style to the power of perceptual style in predicting L2 reading comprehension scores was also sought. Table 4 shows the coefficient value of each perceptual style in predicting L2 reading comprehension scores.

Table 4. Coefficients of each perceptual style in prediction power of perceptual styles on L2 reading comprehension scores

\begin{tabular}{lllll}
\hline Model & & Beta & $\mathrm{t}$ & Sig. \\
\hline 1 & (Constant) & & 2.734 & .008 \\
& Visual Learning Style & -.101 & -.743 & .461 \\
& Auditory Learning Style & -.153 & -1.206 & .233 \\
Kinesthetic Learning Style & .106 & .772 & .443 \\
& Tactile Learning Style & .332 & 2.378 & .021 \\
& Individualistic Learning Style & .239 & 1.518 & .135 \\
& Group Learning Style & .192 & 1.161 & .251 \\
\hline
\end{tabular}

As Table 4 shows, only tactile learning style had the strongest unique contribution to explaining L2 reading comprehension. Tactile learning style accounted for $33 \%$ of the variance in L2 reading comprehension scores. The rest of the perceptual styles did not have unique contribution to explaining L2 reading comprehension. However, visual learning style accounted for $10 \%$, auditory learning style for $15 \%$, Kinesthetic learning style for $10 \%$, individualistic learning style for $23 \%$, and group learning style for $19 \%$ of the variances in L2 reading comprehension scores.

\section{Discussion and Conclusion}

This study was an attempt to investigate the correlation between perceptual learning styles and L2 reading comprehension and the contribution of each of these perceptual learning styles to explaining L2 reading comprehension. Results of statistical analyses revealed that only kinesthetic learning style and tactile learning style had significant relationship with L2 reading comprehension and the best predictor of L2 reading comprehension was tactile learning styles.

The results of the study are in line with previous studies showing differences in learning due to differences in learning styles (e.g., Brown, 1973; Busch, 1982; Gray, 1999). The results also support many claims by scholars regarding the effect of learning styles on academic achievement (e.g., Dunn \& Price, 1977; Robinson \& Gray, 1974). Based on the results of the study, it can be stated that foreign language learners with tactile learning styles are better readers and kinesthetic style is positively related with L2 reading comprehension. This conclusion is consistent with the findings of the study done by Kinsella's (1995) on adult and adolescent ESL language learners. He reported that many adolescent and adult students who were academically challenged within traditional classrooms learned more conveniently through tactile/kinesthetic and visual/nonverbal methods than 
through auditory or visual/verbal methods. However, on the other hand, Carbo (1983) found good readers prefer visual and auditory approaches, while poor readers prefer tactile and kinesthetic style of learning.

It can be put forward that the present findings both support and reject previous findings regarding the effect of perceptual learning styles on L2 learning and reading. However, the results should be interpreted with care and reason. For instance, the role of strategy use was ignored here. It has been reported that learning style greatly influences strategy use (Li \& Qin, 2006). Therefore, it is quite probable that Iranian foreign language learners have been exposed to reading strategies that are more in line with tactile and kinesthetic learning preferences. To be on the safe side, this assumption should be subject to further empirical research. Moreover, teaching styles is another contributing variable that has great effect on students learning (Carrell, 1998). There is also the possibility that the teaching styles Iranian foreign language learners have been accustomed to are more consistent with tactile and kinesthetic styles of learning. This last point also needs to be examined through further empirical research.

The results of the study inform foreign language teachers to be well aware of the students' perceptual learning styles and the ways they affect students' learning and approaches to reading. In this way, teachers can modify their teaching methods in such a way that would be better tailored to various styles of learning within foreign language reading courses.

\section{References}

Aebunthnott, K. D., \& Kratzig, G. P. (2015). Effective teaching: Sensory learning styles versus general processes. Innovative Teaching, 4(2), 1-9.

Asselin, S. B., \& Mooney, M. (1996). Diverse learners: Strategies for success. Glen Allen,VA: Virginia Vocational Curriculum and Resource Center (ED 406 529).

Aydogan, H., \& Akbarov, A. A. (2014). The role of gender, age, academic achievement, LLS and learning styles at tertiary level in EFL classes at Turkey. Journal of Second and Multiple Language Acquisiton, 2(2), 11-24.

Brown, R. (1973). A first language:The early stages. Cambridge, MA: Harvard University Press. http://dx.doi.org/10.4159/harvard.9780674732469

Busch, D. (1982). Introversion-extroversion and the EFL proficiency of Japanese students. Language Learning, 46(1), 109-132. http://dx.doi.org/10.1111/j.1467-1770.1982.tb00521.x

Butler, K. A. (1988). Learning and teaching style: In theory and practice. Columbia, CT: Learner's Dimension.

Carbo, M. (1983). Research in reading and learning style: Implications for exceptional children. Exceptional Children, 49(4), 486-494.

Carrell, P. L. (1998). Can reading strategies be successfully taught? Australian Review of Applied Linguistics, 21(1), 1-20.

Chastain, K. (1988). Developing second language skills. Theory and practice (3rd ed.). Chicago: Harcourt Brace Jovanovich Publisher.

Darnton, R. (1984). Theorigins of modern reading. The New Republic, 190(8), 26-33.

Dunn, R. K., \& Price, G. E. (1977). Diagnosing learning styles: A prescription for avoiding malpractice suits. Phi Delta Kappan, 58(4), 418-420.

Dunn, R. S., \& Dunn, K. J. (1979). Learning styles/teaching styles: Should they... can they... be matched. Educational leadership, 36(4), 238-244.

Durgunoglu, A., \& Hancin-Bhatt, B.(1992). The role of first language in the second-languagereading process. Education University of Illinois at Urbana-Champaign 174 Children's Research Center.

Ellis, R. (2008). Second language acquisition. The United States: Oxford.

Erfanpour, M. (2013). The effect of intensive and extensive reading strategies on reading comprehension: A case of Iranian high school students. English for Specific Purposes World, 41(14), 896-908.

Estadt, M. J. (1997). The relationship between learning styles and personality types of students enrolled in an agricultural teaching methods class. Retrieved from http://etd.ohiolink.edu/send-pdf.cgi/EstadtMichael John.pdf

Garcia, G. E. (2000). Bilingual children's reading. In M. L. Kamil, P. B. Mosenthal, \& P. D. Pearson (Eds.), Handbook of reading research (pp. 813-834). 
Garner, R., \& Alexander, P. A. (1989). Metacognition: Answered and unanswered questions. Educational Psychologist, 24(1), 143-158. http://dx.doi.org/10.1207/s15326985ep2402_2

Gentry, J. W. (1990). What is experiential learning. Guide to business gaming and experiential learning, 9-20.

Gorsuch, G. (2012). Fluency instruction in reading in a second or foreign language. Fluency Instruction: Research-Based Best Practices, 12(2), 255-237.

Grabe, W. (1991). Current developments in second language reading research. TESOL Quarterly, 25(3), 375-406. http://dx.doi.org/10.2307/3586977

Gray, D. E. (1999). The Internet in lifelong learning. International Journal of Lifelong Education, 18(2), 119-126. http://dx.doi.org/10.1080/026013799293874

Griggs, S. A. (1991). Learning styles counseling. ERIC Digest. Ann Arbor: ERIC Clearinghouse on Counseling and Personnel Services, University of Michigan.

James, W. B., \& Gardner, D. L. (1995). Learning styles: Implications for distance learning. New Directions Adult \& Continuing Education, 67(1), 19-31. http://dx.doi.org/10.1002/ace.36719956705

Kinsella, K. (1995). Understanding and empowering diverse learners. In J. M. Reid (Ed.), Learning styles in the ESL/EFL classroom (pp. 108-117). Boston: Heinle \& Heinle Publishers.

Kratzig, G. P., \& Arbuthnott, K. D. (2006). Perceptual learning style and learning proficiency: A test of the $\begin{array}{lllll}\text { hypothesis. Journal of Educational Psychology, } & \text { 98(1), 238-246. }\end{array}$ http://dx.doi.org/10.1037/0022-0663.98.1.238

Larrabee, F. (2005). A comprehensive study of the relationship between personality type and learning styles of students as they apply to the classroom teacher. Retrieved from http://www2.uwstout.edu/content/lib/thesis/2005/2005larrabeef.pdf

Le Sage, T. A., Venneman, S. S., Patton, B. A., \& Hallock, D. E. (2008). Business undergraduate temperaments, student electronic activity, and selected demographic characteristics on course achievement in an on-line university learning environment. European Journal of Social Sciences, 5(4), 8-20.

Lee, D., \& Kim, H. (2014). What can we learn from our learners' learning styles? English Language Teaching, 7(9), 118-131. http://dx.doi.org/10.5539/elt.v7n9p118

Li, J., \& Qin, X. Q. (2006). Language learning styles and strategies of tertiary-level English learners in China. RELC Journal, 37(1), 67-89. http://dx.doi.org/10.1177/0033688206063475

McCarthy, B. (1990). Using the 4MAT system to bring learning styles to schools. Educational Leadership, 48(2), 31-36.

Mikulecky, P. S. (2008). Teaching reading in a second language. New York: Pearson Education.

Mitchell, H., \& Myles, F. (1988). Second language learning theories. London: Arnold.

Nunan, D. (1991). Language teaching methodology: A textbook for teachers. Hertfordshire: Prentice Hall International.

Nunan, D. (1998). Language teaching and methodology. London: Prentice Hall.

Nuttall, C. (1996). Teaching reading skills in a foreign language (New Edition). Oxford: Heinemann.

Pang, E., \& Kamil, M. (2004). Second-language issues in early literacy and instruction. Stanford University. USA.

Pourhossein Gilakjani, A. (2012). Visual, auditory, Kinaesthetic learning styles and their impacts on English language teaching. Journal of Studies in Education, 2(1), 104-113. http://dx.doi.org/10.5296/jse.v2i1.1007

Reid, J. M. (Ed.). (1995). Preface. In J. Reid (Ed.), Learning styles in the ESL/ EFL classroom (pp. viii-xvii). New York: Heinle \& Heinle Publishers.

Riazi, A., \& Mansoorian, M. A. (2008). Learning style preferences among Iranian male and female EFL students. The Iranian EFL Journal, 2(1), 88.

Robinson, J. E., \& Gray, J. S. (1974). Cognitive styles as a variable in school learning. Journal of Educational Psychology, 66, 793-799. http://dx.doi.org/10.1037/h0037487

Salmani-Nodoushan, M. A. (2007). Is field-dependence or independence a predictor of EFL reading performance? TESL Canada Journal, 24(2), 82-108. 
Scarcella, R. (1990). Teaching language minority students in the multicultural classroom. Englewood, New Jersey: Prentice Hall Regents.

Shi, C. (2011). A study of the relationship between cognitive styles and learning strategies. Higher Education Studies, 1(1), 20-26. http://dx.doi.org/10.5539/hes.v1n1p20

Sims, R. R., \& Sims, S. J. (1995). The importance of learning styles: Understanding the implications for learning, course design, and education. Westport, CT: Greenwood Press.

Soozandehfar, M. A., \& Soozandehfar, M. (2011). The effects of field-dependent/field-independent cognitive styles and gender on second language speaking performance. California Linguistic Notes, 36(2), 1-21.

Swanson, L. J. (1995). Learning styles: A review of the literature. The Clarmont Graduate School. (ERIC Document Reproduction Service No. 387067).

Tahriri, A., Divsar, H., \& Ashouri, F. (2015). The relationship between EFL learners' personality types and their cognitive learning styles. International Journal of Research Studies in Language Learning, 4(2), 21-32. http://dx.doi.org/10.5861/ijrsll.2014.843

Tight, D. G. (2010). Perceptual learning style matching and L2 vocabulary acquisition. Language Learning, 69(4), 792-833. http://dx.doi.org/10.1111/j.1467-9922.2010.00572.x

Tuan, L.T. (2011). Teaching writing through genre-based approach. Theory and Practice in Language Studies, 1(11), 1471-1478. http://dx.doi.org/10.4304/tpls.1.11.1471-1478

Yang, L., \& Wilson, K. (2006).Second language classroom reading: A social construct approach. The Reading Matrix, 6(3), 312-321.

\section{Copyrights}

Copyright for this article is retained by the author(s), with first publication rights granted to the journal.

This is an open-access article distributed under the terms and conditions of the Creative Commons Attribution license (http://creativecommons.org/licenses/by/3.0/). 